\title{
Endoreduplication as a part of flower ontogeny in Trifolium pratense cultivars
}

\author{
Valéria Kocová1* Nikola Straková ${ }^{2}, V^{\prime}$ ladislav Kolarčik', Albert Rákai ${ }^{1}$ and Pavol Mártonfi ${ }^{1}$
}

\begin{abstract}
Background: Endoreduplication appears in numerous plant species and plays a vital role during ontogeny. The presence of polyploid cells in an otherwise diploid organism is tied specifically to the taxonomy, ecology and physiology of the studied specimen. Little is known about the changes in endopolyploidy levels of floral organs during their development. In order to uncover the workings of endoreduplication in polysomatic species, our study examines flowers of T. pratense in three ontogenetic stages by means of flow cytometry.

Results: Cultivar 'Manuela' is characterized by the presence of $2 \mathrm{C}-8 \mathrm{C}$ and 'Dajana' $2 \mathrm{C}-16 \mathrm{C}$ nuclei. In general, the frequencies of nuclei only slightly changed during development. Endopolyploidy levels represented by endoreduplication index (EI) in the 'Manuela' sepals and stamens showed statistical differences between young and old stages, other organs of both cultivars between stages are not statistically different. Significant differences between 'Manuela' and 'Dajana' cultivars were found only in sepals of I. stage, and in petals and carpels of III. stage. Cultivars showed a similar pattern of endopolyploidy. However, a considerable decrease in El 'Manuela' petals and carpels at III. stage was detected as opposed to 'Dajana'. Overall, a higher endoreduplication index is distinctive for organs of the 'Dajana' cultivar.
\end{abstract}

Conclusions: In this study we prove the permanent presence of endopolyploid cells in the floral organs of T. pratense throughout their development.

Keywords: Endoreduplication, Trifolium pratense, Flower ontogeny, Ploidy level

\section{Background}

The phenomenon of endopolyploidy is very common in eukaryotic organisms and is distributed across the whole plant kingdom (Barow 2006). It results from endoreduplication. Under certain conditions this process causes a cell to switch from the mitotic to the endoreduplication cycle (Carvalheira 2000; Joubés and Chevalier 2000; Barow and Meister 2003; Leitch et al. 2013). Endoreduplication is characterized by the lack of M-phase of the cell cycle leading to several repeated rounds of DNA synthesis. Thus, the DNA content of a cell multiplies (Barow 2006; Barow and Jovtchev 2007).

The true biological significance of this phenomenon is not yet fully understood (Kudo and Kimura 2002b; Kudo

\footnotetext{
*Correspondence: valeria.kocova@upjs.sk

${ }^{1}$ Department of Botany, Faculty of Science, Institute of Biology and Ecology, P.J. Šafárik University, Mánesova 23, 04154 Košice, Slovakia Full list of author information is available at the end of the article
}

et al. 2004; Leitch et al. 2013; Kron 2015) and new challenges still appear (Trávníček et al. 2015). There are some indications that endoreduplication is involved in the early process of growth and differentiation (Kondorosi et al. 2000). It is often present in cells with high metabolic activity and progressive growth (Cebolla et al. 1999), therefore it implies its role in the enlargement of the size of the cell and serves as a trigger for organ growth (Bourdon et al. 2012). Agricultural crops such as Lycopersicon esculentum (Smulders et al. 1994), Raphanus sativus (Kudo and Kimura 2002a), Solanum tuberosum (Ujtewaal 1987), Zea mays (Engelen-Eigles et al. 2000) and ornamental species (e.g. Dianthus caryophyllus, Agulló-Antón et al. 2013) are endopolyploid. This suggests potential of endopolyploidy alterations in the improvement of growth in these plants.

The occurrence of endopolyploidy has commonly been studied in vegetative organs (Barow and Meister 
2003; Yang and Loh 2004; Sliwinska and Lukaszewska 2005; Kolano et al. 2008; Bainard et al. 2012; Straková et al. 2014), but quite rarely in floral organs of seed plants (Barow and Meister 2003), except for a few detailed studies of orchid flowers (Kudo and Kimura 2001a; Lee et al. 2004; Jean et al. 2011; Trávníček et al. 2015), carnations (Agulló-Antón et al. 2013) and clovers (Kocová et al. 2014). All these studies showed that endopolyploidy is organ- and tissue- specific. Generally, cotyledons, petioles and lower leaves are characterized by higher degrees of endopolyploidy, while roots, upper leaves and floral organs usually show much lower degrees (Barow 2006).

The level of endopolyploidy varies during the individual organ development, e.g. in seedlings (Brassica oleracea, Kudo and Kimura 2001b; Allium fistulosum, Kudo et al. 2003; Beta vulgaris, Sliwinska and Lukaszewska 2005; Chenopodium quinoa, Kolano et al. 2008; and Trifolium pratense, Straková et al. 2014), young leaves and root parts (Spathoglottis plicata, Yang and Loh 2004), or storage organs and nutrient tissues (Lycopersicon esculentum, Bergervoet et al. 1996; Capsicum annum, Ogawa et al. 2012 and Sorghum bicolor, Kladnik et al. 2006), which implies a role of endoreduplication in the developmental process.

Endopolyploidy is related to its taxonomic position in phylogenetic systems (Barow and Meister 2003). The Fabaceae is considered as a family with a very high frequency of endopolyploid species (Barow and Meister 2003; Barow and Jovtchev 2007) including the genus Trifolium (Barow and Meister 2003; Kocová and Mártonfi 2011; Kocová et al. 2014) whose phylogeny and species relationship was thoroughly studied (Ellison et al. 2006). Previous research on the species Trifolium pratense (Straková et al. 2014) showed how the endopolyploidy level varies during the development of organs in seedlings. Endopolyploidy in floral organs during ontogeny is researched here to complete the overall picture of endopolyploidy in $T$. pratense. This report significantly contributes to the research on endopolyploidy, since there is not much knowledge about developmental changes in endopolyploidy levels of floral organs and only a limited number of research studies on petal development have been published so far, e.g. on cabbage (Kudo and Kimura 2002b), carnations (Agulló-Antón et al. 2013) and orchids (Lee et al. 2004).

\section{Methods}

\section{Plant material}

Seeds of Trifolium pratense L., commercial cultivars 'Manuela' and 'Dajana' cultivated in laboratories were germinated in sand for approximately 3 weeks under controlled conditions, $12 \mathrm{~h}$ photoperiod (12 h day, $12 \mathrm{~h}$ darkness), 28/20 ${ }^{\circ} \mathrm{C}$ temperature and 60\% humidity. After germination, seedlings were transferred into pots with a slightly modified Hoagland solution (Hoagland and Amon 1950) which contained macronutrients $\left[(\mathrm{g} / \mathrm{l}) 0.9517 \mathrm{Ca}\left(\mathrm{NO}_{3}\right)_{2}, 0.06 \mathrm{NH}_{4} \mathrm{H}_{2} \mathrm{PO}_{4}, 0.6106 \mathrm{KNO}_{3}\right.$, $0.4905 \mathrm{MgSO}_{4} \cdot 7 \mathrm{H}_{2} \mathrm{O}$ ], $1 \mathrm{~mL}$ solution of micronutrients $\left[(\mathrm{g} / \mathrm{l}) 0.5983 \mathrm{H}_{3} \mathrm{BO}_{3}, 0.4016 \mathrm{MnCl}_{2} \cdot 4 \mathrm{H}_{2} \mathrm{O}, 0.0903\right.$ $\mathrm{ZnSO}_{4} \cdot 7 \mathrm{H}_{2} \mathrm{O}, 0.0524 \mathrm{CuSO}_{4} \cdot 5 \mathrm{H}_{2} \mathrm{O}, 0.0204 \mathrm{CoCl}_{2} \cdot 6 \mathrm{H}_{2} \mathrm{O}$, $\left.0.0288 \mathrm{Na}_{2} \mathrm{MoO}_{4}\right]$ and $1 \mathrm{~mL}$ solution of Fe [(g/l) 26.1 EDTA, $16.1568 \mathrm{KOH}, 24.9 \mathrm{FeSO}_{4} .7 \mathrm{H}_{2} \mathrm{O}$ ]. Plants were cultivated under controlled conditions with a $16 / 8$ photoperiod (16 h day, $8 \mathrm{~h}$ darkness), $28 / 20{ }^{\circ} \mathrm{C}$ temperature and $60 \%$ humidity. Endopolyploidy was estimated in the following organs: sepals, petals, stamens and carpels. The flower ontogeny was divided into three stages (I-III, Fig. 1). The first stage was characterized by completely closed flowers (Fig. 1a), second stage flowers were fully opened (Fig. 1b) and at stage III the flowers bore/exhibited signs of aging (wilting, Fig. 1c).

\section{Karyological analysis}

For chromosome number counting, seeds of Trifolium pratense 'Manuela' were germinated in a Petri dish on a wet filter paper at room temperature. After two days, roots approximately $2-5 \mathrm{~mm}$ long were collected. The root tips were pre-treated in $0.002 \mathrm{M}$ aqueous solution of 8 -hydroxyquinoline for $4 \mathrm{~h}$, fixed in acetic ethanol (acetic acid and 97\% ethanol in the ratio 1:3), washed with distilled water and hydrolysed for $5 \mathrm{~min}$ in $1 \mathrm{~N} \mathrm{HCl}$ at $60{ }^{\circ} \mathrm{C}$. The root tip meristems were washed in distilled water again and then squashed in $45 \%$ acetic acid using the cellophane square technique (Murín 1960). After that the slides were stained with $10 \%$ aqueous solution of Giemsa stock solution and after $24 \mathrm{~h}$ they were washed in distilled water and air-dried. Chromosomes were counted in a drop of immersion oil at 100× using a Leica DM 2500 microscope equipped with a DFC 290 HD camera, using the Leica ver. 3 application suite software.

\section{Flow cytometry preparation}

We used flow cytometry (FCM) for high speed genome analysis, measuring the fluorescence of stained nuclei in our samples. We followed the standard 3 day method (Greilhuber and Obermayer 1997) using the leaves of Trifolium pratense 'Manuela' and 'Dajana'. As an internal reference standard Solanum lycopersicum 'Stupicke polní tyčkové ranî' (2C DNA content $=1.96$ pg, Doležel et al. 1992) was used. A small piece of a fresh leaf of $T$. pratense and of the reference standard were chopped together with a sharp razor blade in a Petri dish containing $1 \mathrm{ml}$ ice-cold GPB (general purpose buffer: $0.5 \mathrm{mM}$ spermine $\times 4 \mathrm{HCl}, 30 \mathrm{mM}$ sodium citrate, $20 \mathrm{mM}$ MOPS [MOPS $=$ 4-morpholine propane sulfonate], 

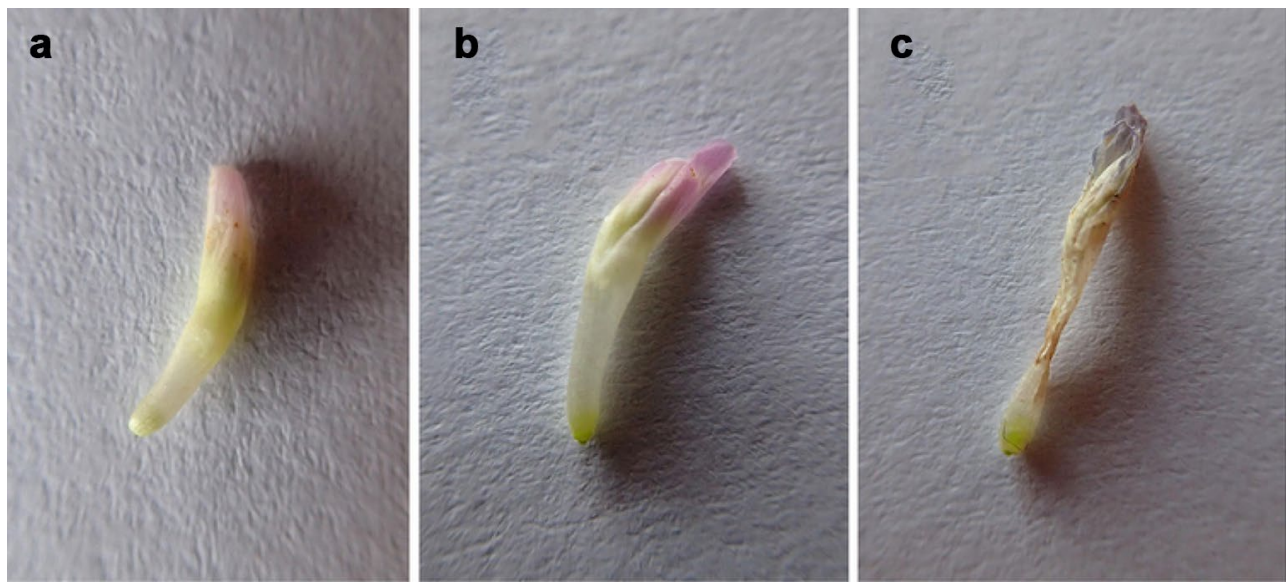

Fig. 1 Developmental stages of floral organs of Trifolium pratense L.: stage I-a, stage II-b, stage III-c

$80 \mathrm{mM} \mathrm{KCl}, 20 \mathrm{mM} \mathrm{NaCl}, 0.5 \%$ [v/v] Triton X-100, pH 7.0, according to Loureiro et al. (2007). The suspension was filtered through a $42 \mu \mathrm{m}$ nylon mesh and each sample was stained separately using $10 \mu \mathrm{g}$ propidium iodide (PI), $10 \mu \mathrm{g}$ RNase and $2 \mu \mathrm{l} \beta$-mercaptoethanol. For the DNA content estimation of the isolated nuclei the Partec CyFlow ML flow cytometer with green solid state laser (532 nm wavelength and $150 \mathrm{~mW}$ ) and bandpass $590 \mathrm{~nm}$ optical filter was used. The data were plotted on a linear scale and processed with the FloMax 2.70 software. At least 1300 nuclei were measured for the standard and sample peaks and only measurements with coefficients of variation below $5 \%$ were used. To evaluate the histograms, the WinMDI 2.9 application was used (Trotter 2000).

Samples for the endopolyploidy analysis were prepared from the floral organs of two Trifolium pratense cultivars in three ontogenetic stages (I-III). 15 flowers were removed from each inflorescence. Pooled organs of the same type were co-chopped ( 15 per sample) following the same procedure as in the genome size measurements. In this case, no reference standard was added. The data for the determination of endopolyploidy were displayed on a logarithmic scale. At least 5000 nuclei were counted for each sample. Processing of the data and the histograms were evaluated as stated above.

\section{Calculation of genome size}

Data visualized by histograms using the flow cytometry software were used for genome size estimations. The calculation of the genome size was made as follows (Doležel and Bartoš 2005):

$2 \mathrm{C}$ DNA content of the sample $=$ mean peak position of the $2 \mathrm{C}$ sample/mean peak position of the $2 \mathrm{C}$ reference standard $\times 2 \mathrm{C}$ DNA content of the reference standard (pg).

\section{Calculation of endopolyploidy}

The degree of endopolyploidization is quantified by a parameter called the endoreduplication index (EI) (Bainard et al. 2012), previously known as a cycle value (Barow and Meister 2003) which indicates the mean number of endoreduplication cycles per nucleus. Endoreduplication index can be calculated as follows (Bainard et al. 2012; Barow and Meister 2003):

$$
\begin{gathered}
\mathrm{EI}=\left(0 \times \mathrm{n}_{2 \mathrm{C}}+1 \times \mathrm{n}_{4 \mathrm{C}}+2 \times \mathrm{n}_{8 \mathrm{C}}+3 \times \mathrm{n}_{16 \mathrm{C}} \ldots\right) / \\
\left(\mathrm{n}_{2 \mathrm{C}}+\mathrm{n}_{4 \mathrm{C}}+\mathrm{n}_{8 \mathrm{C}}+\mathrm{n}_{16 \mathrm{C}} \ldots\right)
\end{gathered}
$$

where $\mathrm{n}_{2 \mathrm{C}}, \mathrm{n}_{4 \mathrm{C}}, \mathrm{n}_{8 \mathrm{C}}, \mathrm{n}_{16 \mathrm{C}}, \ldots$ indicate the counts of nuclei of corresponding C-levels (2C, 4C, 8C, 16C...). Samples with the EI higher than 0.1 are considered endopolyploid (Barow and Meister 2003).

\section{Statistical methods}

Calculated endopolyploidy index data were subjected to statistical analyses of mean or median similarity. Assumptions of parametric tests, data normality and homogeneity of variance were tested using Shapiro-Wilk and Levene test (or $F$ test for equal variance when two groups were compared), respectively. The statistical analysis ANOVA (one-way analysis of variance) was used to determine the differences among corresponding organs and individual developmental stages. If the assumptions of ANOVA were not met a non-parametric, alternative Kruskal-Wallis test was employed. Pairwise comparisons were then performed with Tukey's or Mann-Whitney (with Bonferroni corrected $p$ values to determine 
significance) pairwise post hoc tests. When comparing two groups (comparisons between cultivars), a t test was used instead, in case of unequal variances $p$ value was determined using a permutation test. All tests were carried out as implemented in Past 3.10 software (Hammer et al. 2001).

\section{Results}

The investigated plants of $T$. pratense were confirmed to be diploids with $2 \mathrm{n}=2 \mathrm{x}=14$ chromosomes (Fig. 2). The genome size is approximately $2 \mathrm{C}=0.93 \mathrm{pg}$ in both 'Manuela' and 'Dajana' cultivars.

Mixoploidy was found in each measured sample of all investigated floral organs (Fig. 3), ranging from $2 \mathrm{C}+4 \mathrm{C}$ to $2 \mathrm{C}-8 \mathrm{C}$ nuclei in 'Manuela' and from $2 \mathrm{C}+4 \mathrm{C}$ to $2 \mathrm{C}-16 \mathrm{C}$ nuclei in 'Dajana' (only a single case showed up to $2 \mathrm{C}-32 \mathrm{C}$; Fig. 4). The proportion of nuclei of particular ploidy levels differs among floral organs in both cultivars. In the sepals and stamens only $2 \mathrm{C}$ and $4 \mathrm{C}$ nuclei were present. The latter within range of mean values 15.7$27.4 \%$ across both organs, three stages and both cultivars. In contrast, higher frequencies of $4 \mathrm{C}$ nuclei (28.3-45.5\%) were found in both petals and carpels and $8 \mathrm{C}$ nuclei in petals (less than $4 \%$ in the II. and III. stage of 'Manuela' and 'Dajana' respectively) and carpels (4.9-11.9\% in all stages). In conclusion, only negligible changes in the nuclei frequency occur during the three ontogeny stages in the studied organs. More notably, in 'Dajana' carpels of the III. stage $16 \mathrm{C}$ and $32 \mathrm{C}$ nuclei were present, but the latter were found only in a single sample and determined by a low number of nuclei. Only minimal differences in the nuclei proportion were observed between both investigated cultivars (Fig. 4). A substantial difference was detected in petals, 'Manuela' had $8 \mathrm{C}$ nuclei already in the II. stage, whereas 'Dajana' contained these nuclei only in the III. ontogenetic stage. An apparent difference among

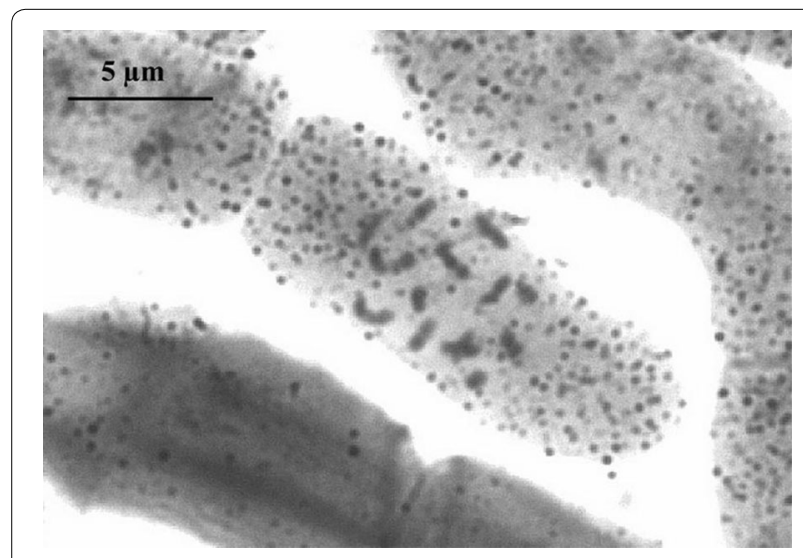

Fig. 2 Somatic chromosomes of Trifolium pratense L. $(2 n=2 x=14)$ cultivars is the maximum ploidy level achieved; while it was $8 \mathrm{C}$ in 'Manuela', there were additional $16 \mathrm{C}$ and even $32 \mathrm{C}$ nuclei recorded in 'Dajana'.

The endopolyploidy level expressed by EI values, varies significantly among the floral organs (ANOVA, $\mathrm{p}<0.05$, Table 1). Generally, higher EI of petals and carpels in comparison with EI of sepals and stamens were found (Table 1). Furthermore, significantly different EI values were observed between carpels and petals in the I. stage of both cultivars. Overall, the highest EI value was recorded in the carpels (0.52 in the I. stage in 'Manuela'; 0.67 in the III. stage in 'Dajana') and the lowest one in the stamens ( 0.16 in the I. stage in 'Manuela'; 0.21 in the I. stage in 'Dajana').

Considering ontogenetic stages within floral organs, the statistical analysis (ANOVA) only showed significant differences in EI $(\mathrm{p}<0.05)$ between stage I and stage III of the 'Manuela' sepals and stamens (Fig. 5). Other differences were insignificant mainly due to relatively high variation among measured samples. Generally, the EI grows gradually with the ontogenetic stage (Fig. 5). However, some exceptions were noticed. While the EI of the 'Dajana' petals increased continuously, a slight drop of EI in the III. stage of the 'Manuela' petals was observed. In the 'Dajana' carpels the EI in the I. stage was 0.56 , then decreased to 0.49 and increased to 0.67 in the II. and III. stage respectively. The rising pattern is broken only in 'Manuela' carpels where the EI decreases from 0.52 in the I. stage to 0.38 in the III. stage. The endopolyploidy pattern is very similar in both cultivars, significant differences were present only in sepals of stage I, and petals of stage III ( $t$ test, $\mathrm{p}<0.05$ ) and carpels of stage III ( $t$ test, $\mathrm{p}<0.01)$.

\section{Discussion}

The number of endocycles in cells is genetically predetermined and the degree of endopolyploidy is subject to the systematic position of the given species (Barow and Meister 2003; Bainard et al. 2012). Only certain families comprise more genera and species with polysomatic organs and tissues (Barow 2006). The presence of endopolyploidy is predominantly found in the family Fabaceae and its genus Trifolium.

Endopolyploid cells were detected in almost all of the investigated organs of $T$. pratense (Kocová and Mártonfi 2011). In this paper we confirmed endopolyploidy in floral organs and uncovered slight differences in overall endopolyploidy levels during flower development. The typical C-level profile of individual floral organs of $T$. pratense cultivars was found rather similar to the previously analyzed wild type $T$. pratense $(2 \mathrm{C}-8 \mathrm{C})$ (Kocová and Mártonfi 2011). This could be accounted for by genetic predisposition in species, and the slight 

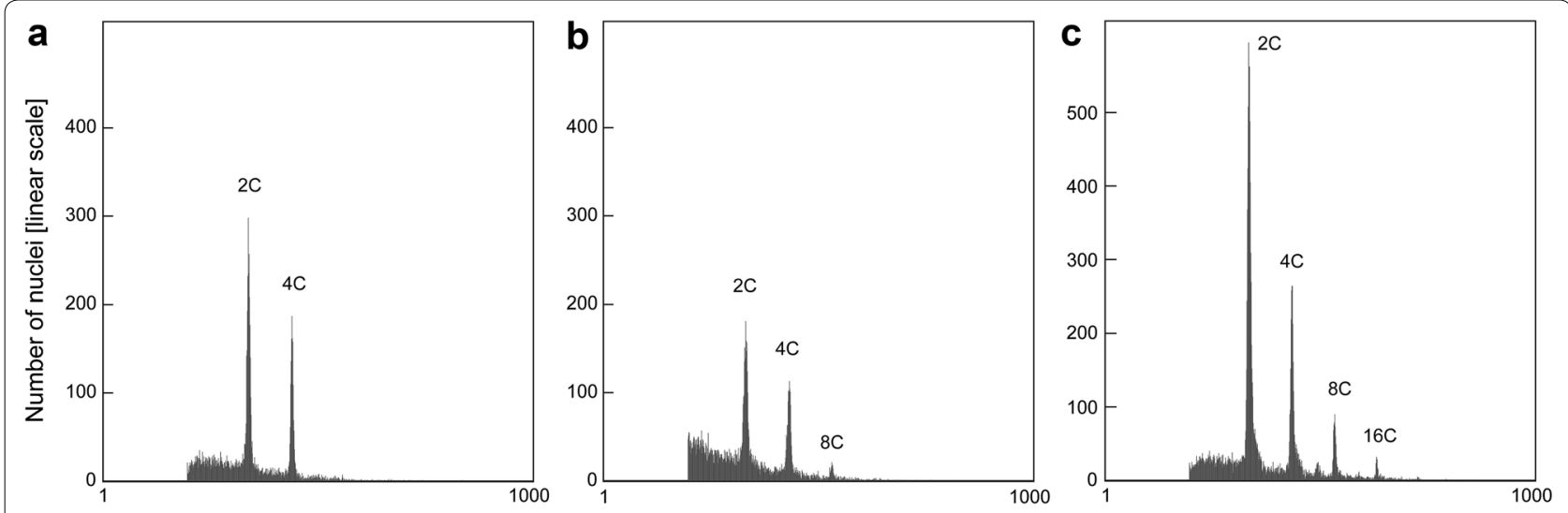

Relative fluorescence intensity [logarithmic scale]

Fig. 3 Histogram examples with typical FCM records showing different ploidy levels of 'Dajana'plants. a Petals in II stage. b Carpels in II stage. c Carpels in III stage

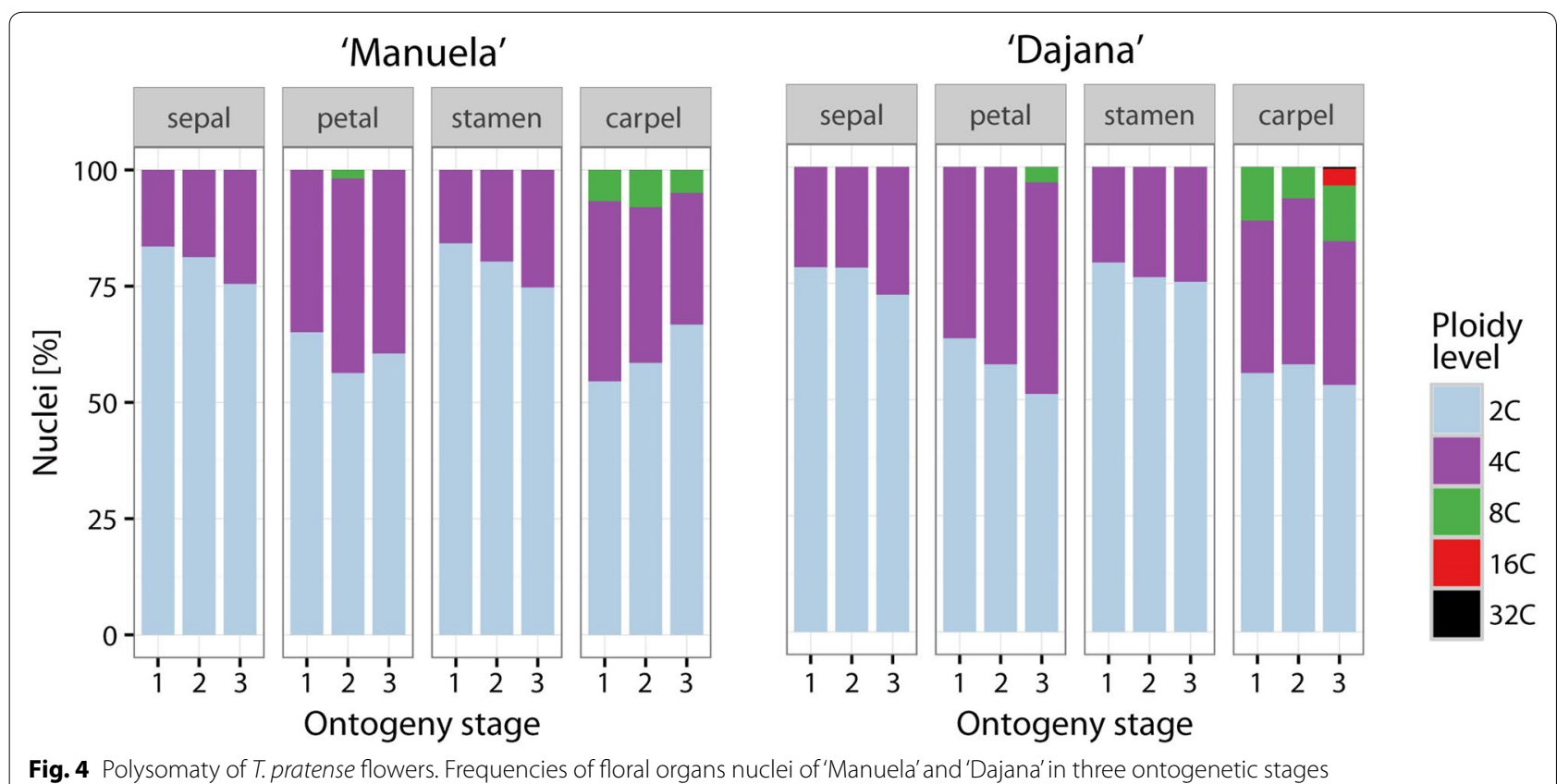

difference recorded between each cultivar and the wild type could result from minor genetic differences or the impact of other external factors (e.g. growing conditions). The endopolyploidy in flowers occurs in many plant groups (Kudo and Kimura 2001a; Fukai et al. 2002; Lee et al. 2004), but in some, even endopolyploid species, e.g. Spathoglottis plicata, endopolyploidy in flowers was not confirmed (Yang and Loh 2004).

Very little is known about the endopolyploidy level during the development of floral organs and its purpose so far. An increasing proportion of endoreduplicated nuclei was detected in the orchid flower development (Lee et al. 2004) as well as in the development of cabbage (Kudo and Kimura 2002b) and carnation petals (Agulló-Antón et al. 2013). We observed a similar situation, although, it seems that the $\mathrm{C}$-values are notably more conserved in the floral organs of T. pratense in comparison with the previous studies. This difference is probably rooted in the species specific features of the genus and a unique developmental pathway of floral organs. We found only subtle (tough still detectable) differences in endopolyploidy levels (EI) of the floral organs between specified stages of the 
Table 1 Summary data of endopolyploidy in Trifolium pratense cultivars 'Manuela' and 'Dajana' in three different ontogeny stages

\begin{tabular}{|c|c|c|c|c|c|c|c|}
\hline \multirow[b]{2}{*}{ Cultivars } & \multirow[b]{2}{*}{ Type of organ } & \multirow[b]{2}{*}{$\mathbf{N}$} & \multirow{2}{*}{$\begin{array}{l}\text { Stage I } \\
\text { El }\end{array}$} & \multicolumn{2}{|c|}{ Stage II } & \multicolumn{2}{|c|}{ Stage III } \\
\hline & & & & $\mathbf{N}$ & EI & $\mathbf{N}$ & El \\
\hline \multirow[t]{4}{*}{ 'Manuela' } & Sepal & 12 & $0.16 \pm 0.04 a$ & 9 & $0.19 \pm 0.08 a$ & 7 & $0.24 \pm 0.07 a$ \\
\hline & Petal & 12 & $0.35 \pm 0.06 b$ & 8 & $0.45 \pm 0.13 \mathrm{bc}$ & 7 & $0.39 \pm 0.06 b$ \\
\hline & Stamen & 6 & $0.16 \pm 0.03 a$ & 4 & $0.2 \pm 0.04 a b$ & 4 & $0.25 \pm 0.05 a b$ \\
\hline & Carpel & 11 & $0.52 \pm 0.12 c$ & 9 & $0.49 \pm 0.06 c$ & 6 & $0.38 \pm 0.11 b$ \\
\hline \multirow[t]{4}{*}{ 'Dajana' } & Sepal & 6 & $0.22 \pm 0.05 a$ & 18 & $0.22 \pm 0.05 a$ & 6 & $0.27 \pm 0.04 a$ \\
\hline & Petal & 6 & $0.37 \pm 0.05 b$ & 17 & $0.42 \pm 0.07 b$ & 6 & $0.52 \pm 0.13 b$ \\
\hline & Stamen & 4 & $0.21 \pm 0.05 a$ & 15 & $0.24 \pm 0.08 a$ & 5 & $0.25 \pm 0.07 a$ \\
\hline & Carpel & 6 & $0.56 \pm 0.04 c$ & 18 & $0.49 \pm 0.11 b$ & 6 & $0.67 \pm 0.17 b$ \\
\hline
\end{tabular}

Values of El are mean \pm standard deviation. Different letters within a column indicate significant differences between organs within one stage at $p<0.05$; both cultivars were treated separately in the statistics

$N$ number of samples, El endoreduplication index

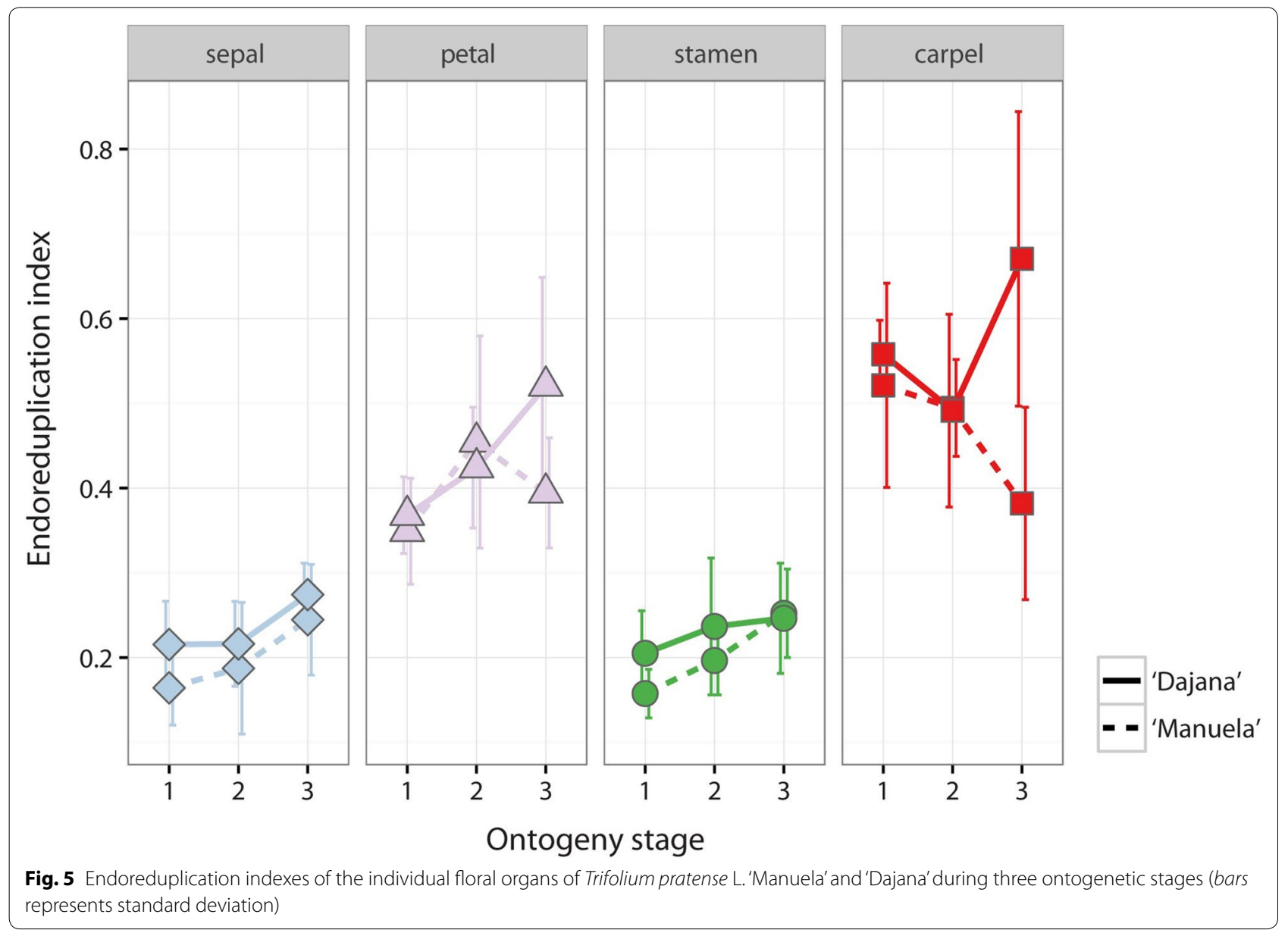

flower development. In general, an increasing tendency in endopolyploidy expression paired with development was detected in the floral organs of T. pratense (Fig. 5). Such trend is also related to other types of organs and tissues of plants, e.g. seedlings (Sliwinska and Lukaszewska 2005; Kolano et al. 2008), endosperm (Kladnik et al. 2006), and pericarp (Bergervoet et al. 1996; Ogawa et al. 2012). Endoreduplication is involved in the growth 
of cells and the development of organs as documented by Kladnik et al. (2006), who stated that cell size and endoreduplication are correlated in Sorghum endosperm. Lee et al. (2004) reported that flower fresh weight is positively correlated with average $\mathrm{C}$-value.

It seems that the endopolyploidy level of the floral organs in T. pratense (Fig. 4) might stabilize close to maturation as seen in orchids (Lee et al. 2004) but the overall EI change in relation to ontogeny was not wholly distinct in our case. However, in contrast to our study, where a continuing change in the endopolyploidy level was recorded even after the maturation of flowers, Lee et al. (2004) found out that in the fully developed flowers of orchids endopolyploidization stops and its ploidy level stabilizes with no further change in the nuclei proportions. Considering this, a difference in the floral life cycle between the two mentioned cases must be noted. Orchid flowers have increased longevity compared to Trifolium, which usually turns to wilting quite rapidly. Changes in EI of petals and carpels could thus be explained by continuous flower development (petals, opening of corolla in the II. stage and senescent wilting in the III. stage; carpels, its likely onset of change to pericarp wall or presence of developed seeds). It is not yet fully understood how endopolyploidy affects developmental processes in sepals, stamens and carpels. Kudo and Kimura (2002b) propose, that the obvious importance of changes in the nuclei size from $2 \mathrm{C}-8 \mathrm{C}$ up to $4 \mathrm{C}-32 \mathrm{C}$ in the proximal epidermal cells of petals in comparison with the distal part of petals (a slight increase of $4 \mathrm{C}$ nuclei), inevitably results in bud opening. This can be the main reason for the ploidy level increase in petal cells.

Despite a very similar pattern in the endopolyploid profile of the floral organs across flower development found in both 'Manuela' and 'Dajana' cultivars, slight differences were detected. Most apparent is the increase in EI in petals and carpels in 'Dajana' when flowers shift to the third stage and its decrease in the same stage within 'Manuela.' This may be the result of developmental process differences between both cultivars, which were not investigated in the present study. Slight differences in endopolyploidy levels in cultivars of the same species are likely, as exemplified by research on carnations (AgullóAntón et al. 2013).

Although the main aim of this study was to determine the changes in endopolyploidy levels in organs during flower ontogeny, other valuable points can be made based on our data. The floral organs in this study showed endopolyploidy patterns similar to the wild type $T$. pratense and other species of the genus, T. repens and T. montanum (Kocová et al. 2014) (similar mean EI of organs, except that of stamens of natural $T$. pratense, which was 0.41 ). In conclusion, common characteristics of the Trifolium species (Kocová and Mártonfi 2011; Kocová et al. 2014) and T. pratense cultivars are (i) EI of petals is always higher than EI of sepals and (ii) the highest EI is found in carpels in comparison with the remaining floral organs. Hence, these seem to be common features in the genus Trifolium. However, this rule should not be applied to species of other families (Barow and Meister 2003; Chen et al. 2011). In addition, endopolyploidy patterns differ in comparison with other Fabaceae species belonging to different genera such as Pisum sativum and Vicia $f a b a$, although the higher EI of petals over sepals corresponds to cases in Trifolium, carpels of the mentioned species were the ones with the lowest EI (Barow and Meister 2003). Putative inconsistency in endopolyploid patterns of the floral organs of different species does not result from coincidence, but is most probably determined by interplay between intrinsic (genetic, cytological, life form) and extrinsic (environmental) factors. It is well known that the endopolyploidy level of organs/tissues is mostly correlated with the phylogenetic placement of the species which is strongly associated with many phenotypic traits (Bainard et al. 2012).

\section{Conclusions}

Endoreduplication serves as the speeding process of the development and growth of floral organs, even though the changes in endopolyploidy of flowers of $T$. pratense during their development are almost negligible. Thus, we assume, while endopolyploidy definitely plays its role during the developmental process of $T$. pratense flowers, the quantitative changes do not speak of significant differences. Recent studies (Kocová and Mártonfi 2011; Straková et al. 2014; this study) provide a comprehensive insight into the endoreduplication pattern of T. pratense, thus proving permanent presence of endoreduplication in the life of plants, starting with seedlings throughout the aging of flowers.

\section{Authors' contributions}

NS and PM conceived of and designed the study. NS and VK carried out the experiments. NS, VK and VKol analyzed and interpreted the data. VKol performed the statistical analysis. NS, VK, VKol, AR and PM composed and drafted the manuscript. All authors read and approved the final manuscript.

\section{Author details}

${ }^{1}$ Department of Botany, Faculty of Science, Institute of Biology and Ecology, P.J. Šafárik University, Mánesova 23, 04154 Košice, Slovakia. ${ }^{2}$ Present Address: Krosnianska 69, 04022 Košice, Slovakia.

\section{Acknowledgements}

Support for this research was provided by the VEGA Grant Agency (Slovakia) no. 1/0163/15 and WVS grant (P. J. Šafárik University in Košice, Slovakia) no. WGS-PF-2015-493. The authors thank to Dr. Lenka Mártonfiová, Dr. Silvia Gajdošová and Dr. Zuzana Kolař́ková who assisted in proof-reading and English language correction. 


\section{Competing interests}

The authors declare that they have no competing interests.

Received: 23 July 2016 Accepted: 22 October 2016

Published online: 27 October 2016

\section{References}

Agulló-Antón MÁ, Olmos E, Pérez-Pérez JM, Acosta M (2013) Evaluation of ploidy level and endoreduplication in carnation (Dianthus spp.). Plant Sci 201-202:1-11

Bainard JD, Bainard LD, Henry TA, Fazekas AJ (2012) A multivariate analysis of variation in genome size and endoreduplication in angiosperms revelas strong phylogenetic signal and association with phenotypic traits. New Phytol 196:1240-1250

Barow M (2006) Endopolyploidy in seed plants. BioEssays 28:271-281

Barow M, Jovtchev G (2007) Endopolyploi-dy in plants and its analysis by flow cytometry. In: Doležel J, Greihulber J, Suda J (eds) Flow cytometry with Plant cells. Wiley-VCH, Weinheim, pp 349-372

Barow M, Meister A (2003) Endopolyploidy in seed plants is differently correlated to systematics, organ, life strategy and genome size. Plant Cell Environ 26:571-584

Bergervoet JHW, Verhoeven HA, Gilissen LW, Bino RJ (1996) High amounts of nuclear DNA in tomato (Lycopersicon esculentum Mill.) pericarp. Plant Sci 116:141-145

Bourdon M, Pirello J, Cheniclet C, Coriton O, Bourge M, Brown S, Moïse A, Peypelut M, Rouyère V, Renaudin JP, Chevalier CH, Frangne N (2012) Evidence for karyoplasmic homeostasis during endoreduplication and a ploidy — dependent increase in gene transcription during tomato fruit growth. Development 139:3817-3826

Carvalheira GMG (2000) Plant polytene chromosomes. Genetics Mol Biol 23:1043-1050

Cebolla A, Vinardell JM, Kiss E, Oláh B, Roudier F, Kondorosi A, Kondorosi E (1999) The mitotic inhibitor ccs52 is required for endoreduplication and ploidy — dependent cell enlargement in plants. EMBO J 18:4476-4484

Chen WH, Tang CY, Lin TY, Weng YC, Kao YL (2011) Changes in the endopolyploidy pattern of different tissues in diploid and tetraploid Phalaenopsis aphrodite subsp. formosana (Orchidaceae). Plant Sci 181:31-38

Doležel J, Bartoš J (2005) Plant DNA flow cytometry and estimation of nuclear genome size. Ann Bot 95:99-110

Doležel J, Sgorbati S, Lucretti S (1992) Comparison of three DNA fluorochromes for flow cytometric estimation of nuclear DNA content in plants. Physiol Plant 85:625-631

Ellison NW, Liston A, Steiner JJ, Williams WM, Taylor NL (2006) Molecular phylogenetics of the clover genus (Trifolium-Leguminosae). Mol Phylogenet Evol 39:688-705

Engelen-Eigles G, Jones RJ, Phillips RL (2000) DNA endoreduplication in maize endosperm cells: the effect of exposure to short-term high temperature. Plant Cell Environ 23:657-663

Fukai S, Hasegawa A, Goi M (2002) Polysomaty in cymbidium. HortScience 37:1088-1091

Greilhuber J, Obermayer R (1997) Genome size and maturity group in Glycine max (soybean). Heredity 7:547-551

Hammer $\varnothing$, Harper DAT, Ryan PD (2001) PAST: Paleontological statistics software package for education and data analysis. Palaeontol Electron 4(1):9

Hoagland DR, Amon DI (1950) The water-cultured method for growing plants without soil. Calif Agr Expt Sta Circ 347:1-32

Jean G-T, Kao Y-L, Tang C-Y, Chen W-H (2011) Distribution of nuclei of different ploidy levels during ovule, seed and protocorm development in Phalaenopsis aphrodite subsp. formosana (Orchidaceae). Am J Plant Sci 2:325-333

Joubés J, Chevalier C (2000) Endoreduplication in higher plants. Plant Mol Biol 43:735-745
Kladnik A, Chourey PS, Pring DR, Dermas-tia M (2006) Development of the endosperm of Sorghum bicolor during the endoreduplication-as-sociated growth phase. J Cereal Sci 43:209-215

Kocová V, Mártonfi P (2011) Endopolyploidy in Trifolium pratense L. Caryologia 64:419-426

Kocová V, Kolarčik V, Straková N, Mártonfi P (2014) Endopolyploidy patterns in organs of Trifolium species (Fabaceae). Acta Biol Cracov Ser Bot $56: 111-120$

Kolano B, Sliwinska D, Maluszynska J (2008) Endopolyploidy patterns during development of Chenopodium quinoa. Acta Biol Cracov Ser Bot 51:85-92

Kondorosi E, Roudier F, Gendreau E (2000) Plant cell-size control: growing by ploidy? Curr Opin Plant Biol 3:488-492

Kron P (2015) Endopolyploidy, genome size, and flow cytometry. Cytom Part A 87:887-889

Kudo N, Kimura Y (2001a) Flow cytometric evidence for endopolyploidization in cabbage (Brassica oleracea L.) flowers. Sex Plant Reprod 13(5):279-283

Kudo N, Kimura Y (2001 b) Patterns of endopolyploidy during seedling development in cabbage (Brassica oleracea L.). Ann Bot 87:275-281

Kudo N, Kimura Y (2002a) Flow cytometric analysis for systemic endopolyploidy development of radish (Raphanus sativus L.). Plant Biotechnol 19:45-52

Kudo N, Kimura Y (2002b) Nuclear DNA endoreduplication during petal development in cabbage: relationship between ploidy levels and cell size. J Ex Bot 53:1017-1023

Kudo N, Ikeda K, Kimura Y, Mii M (2003) The Occurrence of endopolyploid cells during seedling development of Allium fistulosum L. Plant Biotech 20:311-315

Kudo N, Watanabe S, Mii M (2004) Systemic endopolyploidy in development of Spinach (Spinacia oleracea L.). Plant Biotechnol 21:283-287

Lee H-Ch, Chiou D-W, Markhart AH, Chen Y-H, Lin T-Y (2004) Dynamics of cell growth and endoreduplication during orchid flower development. Plant Sci 166:659-667

Leitch IJ, Greilhuber J, Doležel J, Wendel JF (eds) (2013) Plant Genome Diversity, Vol 2. Physical structure, behaviour and evolution of plant genomes. Springer-Verlag, Vienna

Loureiro J, Rodriguez E, Doležel J, Santos C (2007) Two new nuclear isolation buffers for plant DNA flow cytometry: a test with 37 species. Ann Bot 100:875-888

Murín A (1960) Substitution of cellophane for glass covers to facilitate preparation of permanent squashes and smears. Stain Technol 35:351-353

Ogawa D, Ishikawa K, Mii M (2012) Difference in the polysomaty degree during fruit development among plants with different ploidy levels produced by artificial chromosome doubling of a pepper (Capsicum annuum) cultivar 'Shishitou No. 562'. Sci Hortic 134:121-126

Sliwinska E, Lukaszewska E (2005) Polysomaty in growing in vitro sugarbeet (Beta vulgaris L.) seedlings of different ploidy level. Plant Sci 168:1067-1074

Smulders MJM, Rus-Kortekaas W, Gilissen LW (1994) Development of polysomaty during differentiation in diploid and tetraploid tomato (Lycopersicon esculentum) plants. Plant Sci 97:53-60

Straková N, Kocová V, Kolarčik V, Mártonfi P (2014) Endopolyploidy in organs of Trifolium pratense L. in different ontogenetic stages. Caryologia 67:116-123

Trávníček P, Ponert J, Urfus T, Jersáková J, Vrána J, Hřibová E, Doležel J, Suda J (2015) Challenges of flow-cytometric estimation of nuclear genome size in Orchids, a plant group with both whole-genome and progressively partial endoreplication. Cytom Part A 87:958-966

Trotter J (2000) WinMDI (Windows Multiple Document Interface for Flow Cytometry) version 2.9. http://facs.scripps.edu/software.html. Accessed 21 Apr 2013

Ujtewaal BA (1987) Ploidy variability in greenhouse cultured and in vitro propagated potato (Solanum tuberosum) monohaploids $(2 n=x=12)$ as determinated by flow cytometry. Plant Cell Rep 6:252-255

Yang M, Loh CS (2004) Systemic endopolyploidy in Spaglottis plicata (Orchidaceae) development. BMC Cell Biol 5:33 